\title{
Fem år med kursen Lärande för hållbar utveckling - erfarenheter och lärdomar
}

\author{
Stephanie Carlekleva*, Johan Älvgren ${ }^{\mathrm{b}}$, Björn Idlinge ${ }^{\mathrm{c}}$ och Lars Tomsmark ${ }^{\mathrm{d}}$ \\ anstitutionen för design, Linnéuniversitetet; ${ }^{\mathrm{b}}$ Universitetsledningens kansli, Linnéuniversitetet; \\ 'Landsbygdsutvecklare, Växjö kommun, tidigare anställd vid Linnéuniversitetet; ${ }^{\mathrm{d}}$ Institutionen för \\ nationalekonomi och statistik, Linnéuniversitetet
}

\begin{abstract}
Kursen Lärande för hållbar utveckling som vi presenterar i denna artikel är en fortbildningskurs som vänder sig till högskole- och universitetslärare som vill integrera hållbar utveckling i sin undervisning. Målet med kursen är att stärka kompetenser för att undervisa om/i hållbar utveckling utan att vända sig till en specifik disciplin eller ämne. Istälet ligger fokus på möten och samtal kring de globala hållbarhetsutmaningarna som i sig själva skär tvärs över ämnesgränser.

Genom åren har kursen fått uppmärksamhet från olika håll och sedan den första kursomgången 2014 har ett flertal liknande kurser startats vid olika lärosäten i landet, inte sällan på initiativ av tidigare kursdeltagare. Totalt har mer än 50 deltagare genomgått kursen. Bland dem finns alla ämnen representerade och projektarbetena som genomförts på kursen visat på de omfattande och komplexa utmaningar vi står inför och vilka mångfacetterade insatser som behövs. Men det vi har upplevt som det viktigaste med kursen är att den ges till lärare inom alla ämnen och därmed möjliggör möten, kunskaps- och erfarenhetsutbyten över disciplingränserna, något som oftast är väldigt begränsat.
\end{abstract}

Nyckelord: Lärande för hållbar utveckling, fortbildning, högskole- och universitetslärare, hållbar utveckling

\section{INTRODUKTION}

Kursen Lärande för hållbar utveckling, som vi presenterar i denna text, är en fortbildningskurs som vänder sig till högskole- och universitetslärare som vill integrera hållbar utveckling i sin undervisning. Kursen riktar sig till lärare från samtliga ämnesområden med målet att lära sig mer om hållbar utveckling, att stärka kompetenser för att undervisa om/i hållbar utveckling samt inte minst, att lära av varandra över ämnesgränserna, i möten och samtal kring de globala hållbarhetsutmaningarna. En förhoppning med kursen är att den i förlängningen ska stimulera till att fler och fler universitetskurser och program förhåller sig till de hållbarhetsutmaningar vi står inför.

\section{KURSENS UPPLÄGG OCH UTGÅNGSPUNKTER}

Kursen har i huvudsak två fokusområden. Det första undersöker konceptet hållbar utveckling och försöker att kartlägga de globala utmaningarna, medan det andra fokusområdet behandlar teori och praktik av hållbar utveckling i högre utbildning. Dessa två huvudområden är inte strikt separerade då själva formen (hur-frågan) utgör en del av innehållet (vad-frågan).

*Författarkontakt: stephanie.carleklev@lnu.se

Artiklar och reflektioner är kollegialt granskade. Övriga bidragstyper granskas av redaktionen. Se https://hogreutbildning.se ISSN 2000-7558

(C2020 Stephanie Carleklev, Johan Älvgren, Björn Idlinge and Lars Tomsmark. This is an Open Access article distributed under the terms of the Creative Commons Attribution-NonCommercial 4.0 International License (https://creativecommons.org/licenses/by-nc/4.0/), allowing third parties to share their work (copy, distribute, transmit) and to adapt it, under the condition that the authors are given credit, that the work is not used for commercial purposes, and that in the event of reuse or distribution, the terms of this license are made clear.

Citation: Stephanie Carleklev, Johan Älvgren, Björn Idlinge \& Lars Tomsmark (2020) «Fem år med kursen Lärande för hällbar utveckling erfarenheter och lärdomar», Högre utbildning, 10(1), 13-17. https://doi.org/10.23865/hu.v10.1961 


\section{Stephanie Carleklev et al.}

Ända sedan starten har kursen varit öppen för lärare från samtliga ämnen, då de globala hållbarhetsutmaningarna inte låter sig rymmas inom någon specifik disciplin utan skär tvärs över traditionella ämnesgränser (Wals \& Jickling, 2002; O’brian et al., 2013; Barth, 2015). Sammansättningen av kursdeltagare ger möjlighet att mötas och samarbeta över ämnesgränser, något som brukar lyftas fram som viktiga framtida kunskaper för våra studenter (Wiek et al., 20II). Kursdeltagarnas egen undervisning utgör en viktig utgångspunkt, både i diskussioner och i arbetet med kursens projektuppgift. Tanken är att alla kursdeltagare har med sig värdefulla kunskaper och erfarenheter som bidrar till själva kursinnehållet. Delaktighet och inflytande över lärandet brukar lyftas fram som kännetecknande i utbildning för hållbar utveckling (Barth, 20I5), något som i högsta grad har tagits fasta på även i utformningen av denna kurs. En grundläggande fråga kursdeltagarna ska förhålla sig till är "Vilken betydelse har mitt ämne för att möta de globala utmaningarna?"

Under de senaste fem åren har mer än 50 deltagare genomfört kursen, varav ca en fjärdedel från andra lärosäten än Linnéuniversitetet. Kursdeltagarna utgörs i huvudsak av undervisande personal, mer sällan av prefekter och personer i ledande ställning. Det har visat sig finnas ett intresse för kursen även från administrativ personal, vilka inte sågs som målgrupp från början. Behovet av att vidareutbilda sig inom lärande för hållbar utveckling växer även bland dem som arbetar med verksamhetsstöd på fakultets- och universitetsövergripande nivå, i samband med att ämnet blir viktigare inom utbildningar.

Bland kursdeltagarna finns så gott som alla ämnen representerade. Vårdvetenskap, ingenjörsvetenskap, ekonomi, språk och litteratur, konstnärliga ämnen och polisutbildning är enbart några exempel av den breda palett som varit representerad. Inte en enda gång har en deltagare misslyckats i att knyta ämnet hållbar utveckling till sin disciplin på ett meningsfullt sätt. Tvärtom har projektarbetena som genomförts på kursen visat på de omfattande och komplexa utmaningar vi står inför och vilka mångfacetterade insatser som behövs.

Kursen, som planeras och ges av en arbetsgrupp bestående av akademisk och administrativ personal, består av tre schemalagda heldagar med 5-6 veckors uppehåll emellan, då deltagarna arbetar individuellt med ett projektarbete. Undervisningen består av seminarier, gruppdiskussioner och föreläsningar, då bland annat före detta kursdeltagare gästar kursen. De senaste åren har den andra kursträffen bestått av en lunch till lunchträff, en form som har uppskattats av kursdeltagare, då ytterligare möjlighet till fördjupade samtal har möjliggjorts. Som stöd för kursdeltagarna har kursledningen tagit fram en särskild studieguide, vilken länkar till kursmaterial såsom litteratur och videoföreläsningar.

\section{KONKRETA EXEMPEL PÅ INTEGRERING AV HÅLLBAR UTVECKLING I PROJEKTUPPGIFTER}

Kursdeltagarna får i uppgift att genomföra ett projektarbete, vilket inbegriper två delar. Den ena delen handlar om att ta fram någon form av konkret undervisningsmaterial och den andra går ut på att, i en skriftlig projektredovisning, beskriva hur materialet ska användas i undervisningen och vad studenterna förväntas lära sig. Gränsöverskridande möten och dialog värdesätts och möjliggörs under hela kursens gång. Detta gäller även i planering och arbete med projektuppgiften, då projekten presenteras och diskuteras med övriga kursdeltagare och kursledning under kursens gång och innan slutgiltig inlämning.

De flesta projektarbeten handlar om att integrera hållbarhet i enstaka kurser eller moduler. Här finns en otrolig bredd som visar på många olika, och ibland oväntade, sätt på hur man kan närma sig hållbarhet inom vitt skilda ämnen. En kursdeltagare från Institutionen för film och 
litteratur övertygade alla som var lite undrande kring hur man kan förena litteraturvetenskap och hållbarhet genom att undersöka hur apokalypsen behandlas i barn- och ungdomslitteratur och att göra detta till temat för en kurs med studenter. I förslaget undersöktes inte enbart tematiken, utan centralt var även att ge stor plats åt studenternas tankar och funderingar i diskussioner. En annan kursdeltagare med bakgrund inom hotell- och restaurangutbildning undersökte disciplinens hållbarhet och ohållbarhet för att ge en nyanserad bild av utmaningar och möjligheter i en kurs som har som mål att introducera studenter till hållbar matkultur. Även om arbetena oftast genomförs inom det egna ämnet förhåller sig de flesta inte enbart till en dimension av hållbarhet utan har en bred ansats till ämnet. Många arbeten tar också aktivt avstamp i studenternas frågeställningar och bygger på att studenterna kritiskt reflekterar kring hållbarhetsbegreppet.

Mer genomgripande, men mer sällsynt, är projektarbeten som undersöker hur hållbarhet kan integreras i hela utbildningsprogram. Ett projektarbete inom vårdvetenskap gav till exempel en bred översikt över hur strävan efter hållbarhet kommer att påverka disciplinen i framtiden, alltifrån resursanvändning inom vårdmiljöer till förändringar i sjukdomar som sjuksköterskor kommer att möta i sin vardag. Utifrån denna analys utvecklades ett förslag på hur en kurs varje termin inom ett existerande program skulle kunna förändras för att rymma tematiken.

Ännu mer sällsynt är projektarbeten som bygger på interdisciplinära samarbeten. Det finns enbart enstaka exempel som har genomförts över ämnesgränserna. Sedan finns dock en rad projektarbeten som tar sig an att ifrågasätta grundantaganden som disciplinen eller undervisningen vilar på. Detta är arbeten där det görs en vidare tolkning av kursuppgiften och av det efterfrågade undervisningsmaterialet. Ett arbete resonerar till exempel kring dominerande människooch natursyner inom förskole- och bildpedagogik och vad det kan innebära att "arbeta utifrån ett postantropocentriskt perspektiv". Hur påverkas hela utbildningen om man ifrågasätter det dominerande antropocentriska perspektivet, utgående från människan, och istället utforskar alternativa synsätt? Ett annat arbete belyser problematiken kring att formulera examinerbara lärandemål inom den normativa dimensionen av många hållbarhetsfrågor. Detta arbete riktar sig snarare till personal som är inblandad i utvecklingen av kurser och program än direkt till studenter. Författaren skriver själv att arbetet "kan möjligen skapa fler frågor än svar", vilket kan ses som ett gott bidrag till att driva relevanta diskussioner framåt.

\section{ERFARENHETER OCH LÄRDOMAR}

Kursen Lärande för hållbar utveckling inrättades som en fortbildningskurs vid Linnéuniversitetet hösten 2014 på initiativ av universitetsstyrelsen. Kursen har utvecklats kontinuerligt och blev 2018 poänggivande, efter önskemål från ledning och kursdeltagare. Kursen ger möjlighet för universitetet att ta I kap, $5 \$$ i högskolelagen på allvar, och ger utrymme och tid för kursdeltagarna att utveckla sina utbildningar. Kursen har blivit ett viktigt inslag i utbudet av fortbildning för undervisande personal. Dessutom har det visat sig finnas ett behov av fortbildning för flera, så som administrativ personal. Och det har även framförts önskemål om en fördjupad kurs som ett nästa steg.

Genom åren har kursen fått uppmärksamhet från olika håll. Vad som började med en tanke om att utbilda den egna personalen, visade sig attrahera sökande från ett flertal andra universitet och högskolor i Sverige. 2016 lyftes kursen som ett innovativt exempel av sammanslutningen "University Educators for Sustainable Development" (www.ue4sd.eu), ett Copernicus Alliance-projekt med 52 partner (huvudsakligen universitet) från 33 länder som har som mål att utveckla integrering av hållbar utveckling inom högre utbildning. Dessutom har kursen varit 


\section{Stephanie Carleklev et al.}

en av flera bidrag som kunde visas upp när Universitetskanslersämbetet (UKÄ) genomförde tematisk utvärdering av hållbar utveckling inom högre utbildning 20I7. UKÄ bedömde då att "Linnéuniversitetet har en väl utvecklad process för sitt arbete med hållbar utveckling inom utbildning". Sedan den första kursomgången 2014 har ett flertal liknande kurser startats vid olika lärosäten i landet, inte sällan på initiativ av tidigare kursdeltagare från denna kurs.

Det vi har upplevt som det viktigaste med kursen är att den ges till lärare inom alla ämnen och därmed möjliggör möten, kunskaps- och erfarenhetsutbyten över disciplingränserna, något som oftast är väldigt begränsat. Inom den strikta uppdelning i discipliner bör det finnas fler möjligheter till samtal och samarbeten över akademiska gränser, något som också kunde leda till att fler ser interdisciplinära samarbeten som en möjlighet. Samtidigt vill vi lyfta att projektarbeten som har fokuserat på enstaka kurser eller även föreläsningar faktiskt har fördelen att på relativ kort tid kunna omsättas till konkreta undervisningsinslag.

Kursen har blivit något av en plattform för ett bredare samtal om universitetets roll $\mathrm{i}$ att möta de globala hållbarhetsutmaningarna. Vilken roll och vilket ansvar har universitetet som kunskapsproducent, utbildare och samhällsaktör i arbetet för en hållbar framtid? Ett samtal som är av yttersta vikt, då det som sammanfattas i begreppet hållbarhet eller hållbar utveckling i verkligheten utgörs av en rad komplexa utmaningar (Engelman, 20I3). En hållbar utveckling skulle innebära att mänskligheten lyckas med att hitta strategier för hur vi kan skapa ett värdigt liv för alla inom de planetära gränserna (Raworth, 20I2; Folke et al., 20I6). Medan fakta kan hjälpa oss att förstå nuläget och vilka konsekvenser vårt agerande får, så kommer vägen mot hållbarhet kräva att vi kritiskt reflekterar över de inbyggda normer, värderingar och underliggande antaganden som ryms i detta begrepp (O’brian et al., 2013; Barth, 2015). Därför är inte enbart projektarbeten som levererar konkret undervisningsmaterial relevanta, utan även arbeten som ifrågasätter grundantaganden och som väcker fler frågor än svar.

Tyvärr har det också visat sig att medan det finns ett intresse hos relativt många, är tidsbristen ett stort hinder för att söka sig till kursen eller att slutföra den. Samtidigt som universitetsledningen ser behovet och nyttan, har förankringen på fakultetsnivå inte skett i lika stor utsträckning. I slutändan är det mestadels redan engagerad personal som söker sig till kursen baserat på eget intresse, medan det mer sällan görs av strategiska skäl för utveckling av hela program eller programutbud. En sådan mer strategisk utveckling är önskvärd, då förändringar på kursnivå oftast inte är tillräckligt.

De globala utmaningar mänskligheten står inför efterfrågar genomgripande förändringar av våra samhällen på kort tid - förändringar i alla samhällssektorer och på alla nivåer. Om universitetet ska axla sitt ansvar och sin möjlighet att ställa om våra samhällen och skapa en hållbar framtid, kommer det sannolikt att krävas att initiativ liknande kursen Lärande för hållbar utveckling blir en självklarhet för varje lärosäte.

\section{FÖRFATTARPRESENTATION}

Stephanie Carleklev är lektor i design vid Linnéuniversitetet. Hon arbetar huvudsakligen med att undervisa och handleda studenter i design och har under många år varit programansvarig för ett designprogram med inriktning hållbar utveckling. Hennes forskning fokuserar bland annat på hur konstnärliga designutbildningar kan svara på de utmaningar vi står inför. I kursen som beskrivs är hon examinator.

Johan Älvgren arbetar som koordinator för hållbar utveckling vid universitetsledningens kansli, Linnéuniversitetet. Han har medverkat i framtagandet och utvecklingen av den beskrivna kursen alltsedan starten 20I4. Johan har tidigare arbetat med utbildning för hållbar utveckling vid Cemus, Centrum för miljö- och utvecklingsstudier, Uppsala universitet och SLU. 
Björn Idlinge arbetar som landsbygdsutvecklare i Växjö kommun. Han var tidigare verksam som statsvetare vid Linnéuniversitetet, med lång undervisningserfarenhet. Under perioden 20I3-20I8 var han anställd som koordinator för hållbar utveckling vid Linnéuniversitetet. Han har medverkat i framtagandet och utvecklingen av den beskrivna kursen alltsedan starten 2014 .

Lars Tomsmark är universitetsadjunkt i nationalekonomi och har lång erfarenhet av undervisning i olika kurser inom ämnet samt generellt inom utbildningsutveckling. Han började intressera sig för miljöekonomi vid mitten av 1990-talet och utvecklat flera kurser på olika nivåer och med flera syften inom området, både kurser inom ämnet och ämnesövergripande. Med tiden har också kurserna fătt större innehåll av perspektiv som hållbar utveckling.

\section{REFERENSER}

Barth, M. (2015). Implementing sustainability in higher education: learning in an age of transformation. London/New York: Routledge.

Engelman, R. (2013). "Beyond Sustainababble" in Is Sustainability Still Possible?, edited by Linda Starke, 3-16. Washington: Island Press.

Folke, C., Biggs, R., Norström, A.V., Reyers, B. \& Rockström, J. (2016). Social-ecological resilience and biosphere-based sustainability science. Ecology and Society 21(3): 41. http://dx.doi.org/10.5751/ ES-08748-210341

O’Brien, K., Caspari, A., Reams, J. \& Dugmore, A. (2013). You say you want a revolution? Transforming education and capacity building in response to global change. Environmental Science \& Policy, 28: 48-59.

Raworth, K. (2012). A Safe and Just Space for Humanity - Can We Live within the Doughnut? Oxfam Discussion Paper. Oxford: Oxfam GB for Oxfam International.

Wals, A. E. \& Jickling, B. (2002). "Sustainability" in higher education: From doublethink and newspeak to critical thinking and meaningful learning. International Journal of Sustainability in Higher Education, $3(2): 221-232$.

Wiek, A., Withycombe, L. \& Redman, C. (2011). Key competencies in sustainability: a reference framework for academic program development. Sustainability Science, 6(2): 203-218. http://dx.doi.org/10.1007/ s11625-011-0132-6 